\title{
Basmak - A New Type of Tobacco in the Balkans
}

\author{
Ana Korubin- Aleksoska ${ }^{1}$, Mohammad Ayaz Ahmad ${ }^{2}$ \\ ${ }^{I}$ Department of Genetics, Selection and Seed Control, Scientific Tobacco Institute - Prilep, Kicevski pat bb, \\ 7500 - Prilep, University of St. KlimentOhridski - Bitola, Republic of Macedonia \\ ${ }^{2}$ Physics Department,Faculty of Science, University of Tabuk, P.O. Box 741, Zip 71491, Tabuk, Saudi Arabia
}

\begin{abstract}
Investigations were carried out with tenoriental tobaccos of the types: Basmak (MK-1, $M K-2, M B-2$, MB-3, MS-8/1, MS-9/3 and YZ-7), Prilep (Prilep Basma-82), Djebel (Xanthi Djebel-1) and Yaka (YV 125/3), to study: height of the stalk with inflorescence, leaf number, length of the middle belt leaves and dry mass yield per stalk. The trial was set up in the Experimental field of Tobacco Institute-Prilep in 2013 and 2014, in randomized block design with three replications, using traditional agricultural practices.The aim of the investigation is to study some more important quantitative traits of tobacco varieties, to make comparison between variants and to evaluate the variability in all genotypes. This investigation will give precise knowledge of the new type Basmak in Macedonia and the Balkans from genetic, morphological and agronomic aspects. The highest stalk among the investigated genotypes was recorded in Prilep Basma-82. This variety has the highest leaf number and the highest dry mass yield per stalk. MS-9/3 has the longest length of the middle belt leaves. Among the Basmak varieties, YZ-7 is the highest and MC 9/3 has the highest leaf number and yield. Differences between the traits of varieties in the years of investigation are not significant, except for the MS-8/1 for the stalk height and Prilep Basma-82 for the stalk height and leaf number per stalk. This is a sign of high inheritance of the studied traits. The two-year biometric investigations of quantitative traits of the varietiesshow low standard deviation and low coefficient of variability, which indicates stability and uniformity as a result of their homozygotness.
\end{abstract}

Keywords: tobacco (Nicotianatabacum L.); type Basmak, quantitative traits. standard deviation, variability.

\section{Introduction}

Tobacco production has a long tradition in the Republic of Macedonia. The most frequently produced were the oriental tobaccos Prilep, Yaka and Djebel, semi-oriental type Otlia, and much later the large-leaf varieties of the types Virginia and Burley(2004). From 2005, several varieties of the oriental Basma tobacco were included in regular production, at a request of tobacco purchasing companies founded with foreign capital. At present, the Tobacco Institute in collaboration with other companies - participants in the project for creation of new tobaccovarieties has released seven varieties such as Basmak, two of which are already commercialized.

Many breeders have worked on selection and creation of new varieties of Basma tobacco, because of its high quality raw material and high price in tobacco market. There are many studies that indicate the need to increase the production of varieties of this tobacco type. Nikolova, Drachev and Nikolov (2005), in their studies on technological properties of some Basma tobacco varieties grown in different regions of Bulgaria concluded that the varieties grown in the regions where they were traditionally produced had significantly better quality than the same varieties grown in other regions. Drachev, Nikolova and Popova (2006) made comparative trial with Bulgarian varieties of the ecotype Basma and the Greek variety Zihna, located in Djebelian tobacco producing region. In their investigation on the most important chemical parameters and degustational properties of tobacco raw quality they observed significant differences that are the basis for a complex assessment of the average quality and rank of the studied varieties. Drachev, Nikolova and Nikolov (2007) made a comparative trial in the Yaka tobacco producing region to study the technological properties of some domestic varieties of the oriental type Basma and Greek variety Zihna, in accordance with the emerging needs for changes in the varietal structure and placement of tobacco raw in the world market. Analyses were made using a qualitative index to estimate the quality of oriental tobacco, by which it was proved that the introduced varieties can be produced in the above regions. Masheva, Todorova and Dimanov (2009) studied the gene effect in the inheritance of plant height, leaf number per plant, leaf length and width and the period from planting to flowering in two hybrids obtained through interspecific hybridization: Krumovgrad 988 x BasmaXanthi 101 and Harmanly 134 x BasmaXanthi 101. The authors found additive and non-additive genetic effect and gave directions for further selection to obtain stable and uniform lines of Basma tobacco. Nikolov,Drachevand Nikolova(2009) in the research conducted in 2006 compared the chemical and technological traits of tobacco varieties Zihna and Komotini of Greek origin introduced in Bulgaria and the domestic variety Djebel K 81 . The authorsreported that the quality of Zihna was lower than that of Djebel K 81 and the raw material obtained from the Djebelian tobacco producing region had a higher rank. Komotini and Zihna tobaccos grown in the region of 
Nevrokop were characterized by higher uniformity. Gixhari and Sulovari (2010) made three-years investigation (2007-2009) in two different environmental areas in Albania to study the inheritance of some major morphological and biological quantitative traits of eight parental genotypes and their hybrids. They found that the Greek variety BasmaXanthi had the highest stalk of 123,2 cm, with 36.4 leaves per stalk, 19,7 cm length and $12,1 \mathrm{~cm}$ width of the middle belt leaves, 91.9 days from planting to flowering and a yield of $259.6 \mathrm{~kg} / \mathrm{da}$. Dimanov and Masheva (2011) studied the new varieties of Basmatobacco selected in the Institute of Tobacco and Tobacco Products - Markovo (Sekirka,DjebelBasma 1, DjebelBasma 2, Basma 13, Plovdiv 380, Ustina 54, Kozarsko 339 and SrednogorskaYaka) in order to present the newly selected material. Darvishzadeha and HatamiMaleki (2011) made analysis on the genetic variance of 100 Iranian oriental and semi-oriental tobacco genotypes of local and foreign origin for the quantitative traits: days to $50 \%$ flowering, dry mass yield and leaf number per plant.The studied genotypes included varieties of tobacco types Samsoun, Izmir, Basma, Krumovgrad and Nevrokop, which can be grown in tobacco producing regions of Iran and are in accordance with the needs of the world market. Kichukov (2012) reported that over 300000 decares in Bulgaria are grown with oriental tobacco and that Basma varieties are grown in the most poorly productive regions. These are also the lowest-yielding varieties with about $120 \mathrm{~kg} / \mathrm{da}$ and with the highest purchase price. The most suitable regions for growing Basma tobaccos in Bulgaria are GoceDelchev, Haskovo and Kardzhali.

The subject of our research is to study the major quantitative properties of tobacco varieties, to make a comparison between them and to estimate their variability. The investigations will give precise information about the new type Basmak in Macedonia from genetic, morphological and agronomic aspects.

\section{Material and Methods}

The investigations include two-year study (2013 and 2014) on height of the stalk with inflorescence, leaf number per stalk, length of the middle belt leaves and dry mass yield per stalk, inten varieties of the types: Basmak(MK-1 -Fig.1, MK-2 -Fig.2, MB-2-Fig.3, MB-3 -Fig.4, MS-8/1-Fig.5, MS-9/3-Fig.6 and YZ-7 Fig.7), Prilep (Prilep Basma-82 -Fig.8), Djebel (Xanthi Djebel-1 -Fig.9,) and Yaka (YV 125/3-Fig.10). The trial was set up in the Experimental field of Tobacco Institute-Prilep, in randomized block design with three replications, using traditional agricultural practices. Investigations were performed at the stage of full flowering of tobacco, by standard methods. Measurement of dry leaf mass was made after drying the leaves of ten plants per variety from each replication.

During tobacco vegetation in field (May - September) in 2013, mean monthly temperature was $19.4^{\circ} \mathrm{C}$, number of rainy days 34 and total precipitation amount $153 \mathrm{~mm}$. In the same period in 2014 mean monthly temperature was $18.3^{\circ} \mathrm{C}$, number of rainy days 33 and total precipitation amount $223 \mathrm{~mm}$ [8].

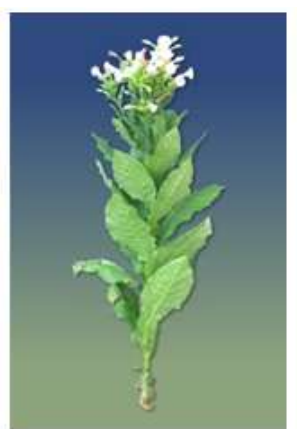

Fig. 1. MK-1

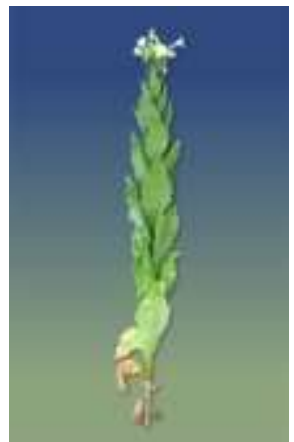

Fig. 6: MS-9/3

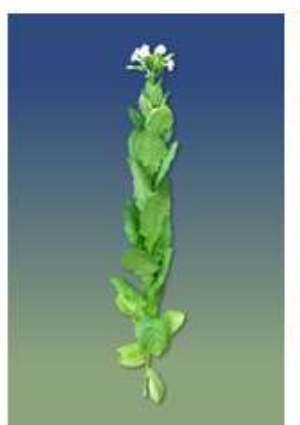

Fig. 2. MK-2

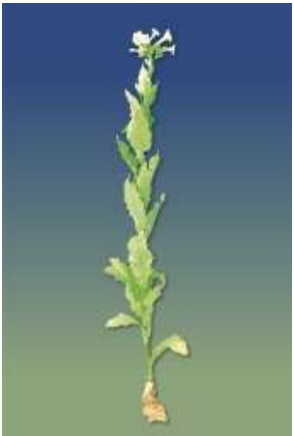

Fig 7: YZ-7

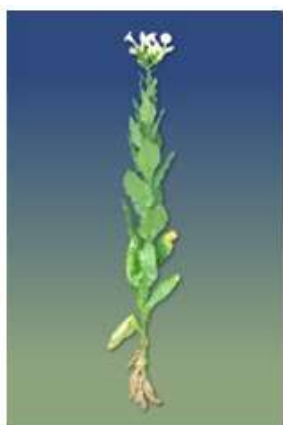

Fig. 3. MB-2

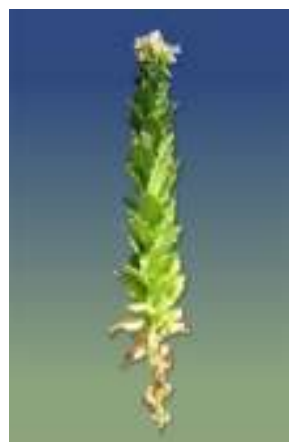

Fig. 8: Prilep Basma -82 Fig. 9. Xanthi Djebel -1

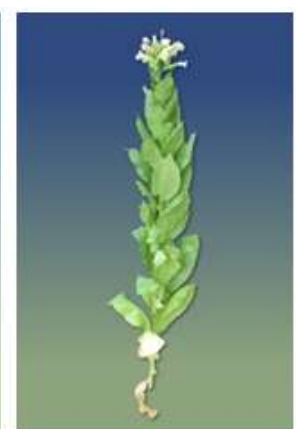

Fig. 5. MS-8/1

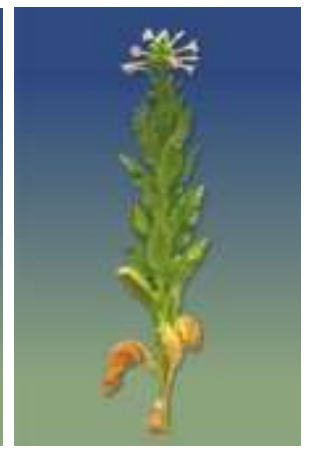

Fig. 10: YV 125/3 


\section{Results and Discussion}

Popular varieties of the type Basma are ranked in the high-quality group of oriental aromatic tobaccos. This type was created from the type Yaka. Introduction and spread of Basma varieties in the Balkans require detailed quantitative and qualitative analysis of their adaptation to the conditions of the new areas of breeding. The name of this new tobacco type in Macedonia is Basmak and it consists of the newly created varieties: MK1, MK-2, MB-2, MB-3, MS-8/1, MS-9/3 and YZ-7, owned by Tobacco Institute-Prilep and tobacco companies participants in the selection project. These varieties were subject for our studies. These varieties were subject of our studies. For a more reliable results, Prilep Basma-82 was included as a superior and Xanthi Djebel-1 as an inferior variety regarding the investigated traits and YV 125/3 was used as a standard variety.

The highest stalk with inflorescence was observed in the varietyPrilep Basma- $82(\bar{x}=145.25 \mathrm{~cm})$, and the lowest in Xanthi Djebel-1 $(\bar{x}=66 \mathrm{~cm})$, which is 79.25 cmlower than the first one. Compared to the YV $125 / 3(\bar{x}=124 \mathrm{~cm})$, the highest variety is $21.25 \mathrm{~cm}$ higher and the lowest variety is $58 \mathrm{~cm}$ lower. The highest variety of Basmak tobacco is YZ-7 with $\bar{x}=118.75 \mathrm{~cm}$, and the lowest is MK-1 with $\bar{x}=88.75 \mathrm{~cm}$ (Table 1).

Analysis of variance for height of the stalk with inflorescenceshowed highly significant differences in 35.00 significant differences in 6 and non-significant differences in 4 combinations. Compared to YV 125/3, all genotypes are significantly different except for YZ-7 (Table 2).

Table 1. Mean value and variability of height of the stalk with inflorescence

\begin{tabular}{|c|c|c|c|c|c|c|}
\hline \multirow{3}{*}{ Varieties } & \multicolumn{6}{|c|}{ Height ofthe stalk withinflorescence $(\mathrm{cm})$} \\
\hline & \multicolumn{3}{|c|}{2013} & \multicolumn{3}{|c|}{2014} \\
\hline & $\bar{x} \pm \mathrm{s} \bar{x}$ & $\delta$ & $\mathrm{V}(\%)$ & $\bar{x} \pm \mathrm{s} \bar{x}$ & $\delta$ & $\mathrm{V}(\%)$ \\
\hline V1-MK-1 & $87 \pm 0.96$ & 4.30 & 4.94 & $90.5 \pm 1.05$ & 4.72 & 5.21 \\
\hline V2-MK-2 & $90 \pm 1.46$ & 6.52 & 7.24 & $93 \pm 1.08$ & 4.85 & 5.21 \\
\hline V3-MB-2 & $93 \pm 1.39$ & 6.20 & 6.67 & $96 \pm 1.44$ & 6.44 & 6.71 \\
\hline V4- MB-3 & $99.5 \pm 1.45$ & 6.50 & 6.53 & $101 \pm 1.35$ & 6.04 & 5.98 \\
\hline V5-MS-8/1 & $105 \pm 1.32$ & 5.92 & 5.63 & $111 \pm 1.56$ & 7.00 & 6.31 \\
\hline V6-MS-9/3 & $112 \pm 1.78$ & 7.97 & 7.11 & $117 \pm 1.14$ & 5.10 & 4.36 \\
\hline V7- YZ-7 & $116 \pm 1.44$ & 6.44 & 5.55 & $121.5 \pm 1.28$ & 5.72 & 4.71 \\
\hline V8-PrilepBasma - 82 & $140 \pm 1.06$ & 4.74 & 3.39 & $150.5 \pm 0.86$ & 3.84 & 2.55 \\
\hline V9-XanthiDjebel - 1 & $65 \pm 1.00$ & 4.47 & 6.88 & $67 \pm 0.96$ & 4.30 & 6.42 \\
\hline V10 - YV 125/3 & $122 \pm 1.14$ & 5.10 & 4.18 & $126 \pm 0.91$ & 4.06 & 3.22 \\
\hline $\begin{array}{l}\text { LSD }_{0.05} \\
0.01\end{array}$ & $\begin{array}{c}5.87 \\
10.56 \\
\end{array}$ & & & $\begin{array}{l}5.35 \\
9.63 \\
\end{array}$ & & \\
\hline
\end{tabular}

Table 2.Significance of differences in height of the stalk with inflorescence among varieties (from the values in Table 1)

\begin{tabular}{|c|c|c|c|c|c|c|c|c|c|}
\hline Differ. & Signi. & Differ. & Signi. & Differ. & Signi. & Differ. & Signi. & Differ. & Signi. \\
\hline $\mathrm{V} 1-\mathrm{V} 2$ & -2.75 & $\mathrm{~V} 2-\mathrm{V} 3$ & -3.00 & $\mathrm{~V} 3-\mathrm{V} 5$ & $-13.50 * *$ & $\mathrm{~V} 4-\mathrm{V} 8$ & $-45.00 * *$ & $\mathrm{~V} 6-\mathrm{V} 8$ & $-30.75^{* * *}$ \\
\hline $\mathrm{V} 1-\mathrm{V} 3$ & $-5.75^{*}$ & $\mathrm{~V} 2-\mathrm{V} 4$ & $-8.75^{*}$ & V3 - V6 & $-20.00 * *$ & $\mathrm{~V} 4$ - V9 & $34.25^{* *}$ & V6 - V9 & $48.5^{* *}$ \\
\hline $\mathrm{V} 1$ - V4 & $-11.50 * *$ & $\mathrm{~V} 2-\mathrm{V} 5$ & $-16.50^{* *}$ & V3 - V7 & $-24.25^{* *}$ & $\mathrm{~V} 4-\mathrm{V} 10$ & $-23.75^{* *}$ & V6 - V10 & $-9.50 *$ \\
\hline $\mathrm{V} 1-\mathrm{V} 5$ & $-19.25^{* *}$ & $\mathrm{~V} 2-\mathrm{V} 6$ & $-23.00^{* *}$ & $\mathrm{~V} 3-\mathrm{V} 8$ & $-50.75^{* *}$ & V5 - V6 & $-6.50^{*}$ & V7 - V8 & $-26.50 * *$ \\
\hline V1 - V6 & $-25.75^{* *}$ & $\mathrm{~V} 2$ - V7 & $-27.25^{* *}$ & V3 -V9 & $28.50 * *$ & V5 - V7 & $-10.75^{* *}$ & V7 - V9 & $52.75^{* *}$ \\
\hline V1 - V7 & $-30.00 * *$ & $\mathrm{~V} 2-\mathrm{V} 8$ & $-53.75^{* *}$ & $\mathrm{~V} 3-\mathrm{V} 10$ & $-29.50^{* *}$ & V5 - V8 & $-37.25^{* * *}$ & V7 - V10 & -5.25 \\
\hline $\mathrm{V} 1-\mathrm{V} 8$ & $-56.50 * *$ & $\mathrm{~V} 2$ - V9 & $25.50 * *$ & V4 - V5 & $-7.75^{*}$ & V5 - V9 & $42.00 * *$ & V8 - V9 & $79.25^{* *}$ \\
\hline V1 - V9 & $22.75^{* *}$ & $\mathrm{~V} 2-\mathrm{V} 10$ & $-32.50 * *$ & V4 - V6 & $-14.25^{* *}$ & $\mathrm{~V} 5-\mathrm{V} 10$ & $-16.00^{* * *}$ & $\mathrm{~V} 8-\mathrm{V} 10$ & $21.25^{* *}$ \\
\hline $\mathrm{V} 1$ - V10 & $-35.25^{* *}$ & $\mathrm{~V} 3$ - V4 & $-5.75^{*}$ & $\mathrm{~V} 4-\mathrm{V} 7$ & $-18.50 * *$ & V6 - V7 & -4.25 & $\mathrm{~V} 9-\mathrm{V} 10$ & $-58.00 * *$ \\
\hline
\end{tabular}

Signi. $-{ }^{*}$ - significance for $5 \% ;^{* *}$ - significance for $1 \%$

Differ. - differences between varieties

The highest leaf number among the varieties was found in Prilep Basma-82 $(\bar{x}=86)$, which had 69 leaves more thanXanthi Djebel-1 ( $\bar{x}=17)$ with the lowest leaf number. Compared to the standard variety YV 125/3 ( $\bar{x}=41)$, Prilep Basma-82 has 45 leaves more and Xanthi Djebel-1 24 leaves less. Among Basmak varieties, tha highest leaf number was recorded in MS-9/3 with $\bar{x}=43.6$, and the lowest in MK-1 with $\bar{x}=28.1$ cm (Table 3).

Analysis of variance for the number of leaves per stalk showed highly significant differences in 34, significant differences in 3 and no-significant differences in 8 combinations. Compared to the standard variety YV 125/3, all genotypes are significantly different except for MS-8/1 and YZ-7 (Table 4). 
Table 3. Mean value and variability of the number of leaves per stalk

\begin{tabular}{|l|c|c|c|c|c|c|}
\hline \multirow{2}{*}{ Varieties } & \multicolumn{7}{|c|}{ Number of leaves per stalk } \\
\cline { 2 - 8 } & $\bar{x} \pm \mathrm{s} \bar{x}$ & $\delta$ & $\mathrm{V}(\%)$ & $\bar{x} \pm \mathrm{s} \bar{x}$ & $\delta$ & $\mathrm{V}(\%)$ \\
\cline { 2 - 8 } & $27.70 \pm 0.30$ & 1.34 & 4.85 & $28.50 \pm 0.31$ & 1.39 & 4.87 \\
\hline V1 - MK-1 & $28.00 \pm 0.33$ & 1.48 & 5.30 & $30.00 \pm 0.40$ & 1.79 & 5.96 \\
\hline V2-MK-2 & $29.50 \pm 0.41$ & 1.83 & 6.20 & $30.00 \pm 0.47$ & 2.12 & 7.07 \\
\hline V3-MB-2 & $33.00 \pm 0.30$ & 1.34 & 4.07 & $34.00 \pm 0.27$ & 1.22 & 3.60 \\
\hline V4-MB-3 & $41.50 \pm 0.50$ & 2.25 & 5.41 & $42.80 \pm 0.41$ & 1.83 & 4.28 \\
\hline V5-MS-8/1 & $43.00 \pm 0.39$ & 1.76 & 4.09 & $44.20 \pm 0.36$ & 1.60 & 3.62 \\
\hline V6-MS-9/3 & $41.00 \pm 0.45$ & 2.02 & 4.94 & $42.00 \pm 0.39$ & 1.76 & 4.19 \\
\hline V7- YZ-7 & $84.00 \pm 0.39$ & 1.73 & 2.06 & $88.00 \pm 0.60$ & 2.70 & 3.07 \\
\hline V8-PrilepBasma - 82 & $17.00 \pm 0.30$ & 1.34 & 7.89 & $17.00 \pm 0.21$ & 0.95 & 5.58 \\
\hline V9-XanthiDjebel - 1 & $40.00 \pm 0.45$ & 2.00 & 5.00 & $42.00 \pm 0.42$ & 1.90 & 4.52 \\
\hline V10-YV 125/3 & 2.20 & & & 2.97 & & \\
\hline $\begin{array}{l}\text { LSD } 0.05 \\
0.01\end{array}$ & 3.96 & & & 5.34 & & \\
\hline
\end{tabular}

Table 4.Significance of differences in number of leaves per stalkamong varieties (from the values in Table 3)

\begin{tabular}{|c|c|c|c|c|c|c|c|c|c|}
\hline Differ. & Signi. & Differ. & Signi. & Differ. & Signi. & Differ. & Signi. & Differ. & Signi. \\
\hline $\mathrm{V} 1-\mathrm{V} 2$ & -0.90 & $\mathrm{~V} 2-\mathrm{V} 3$ & -0.75 & V3 - V5 & $-12.40 * *$ & $\mathrm{~V} 4-\mathrm{V} 8$ & $-52.50 * *$ & V6 - V8 & $-42.40 * *$ \\
\hline $\mathrm{V} 1-\mathrm{V} 3$ & -1.65 & $\mathrm{~V} 2-\mathrm{V} 4$ & $-4.50 *$ & V3 - V6 & $-13.85^{* *}$ & $\mathrm{~V} 4$ - V9 & $16.50^{* *}$ & V6 - V9 & $26.60^{* *}$ \\
\hline $\mathrm{V} 1-\mathrm{V} 4$ & $-5.40 * *$ & $\mathrm{~V} 2-\mathrm{V} 5$ & $-13.15^{* *}$ & $\mathrm{~V} 3-\mathrm{V} 7$ & $-11.75^{* *}$ & $\mathrm{~V} 4-\mathrm{V} 10$ & $-7.50^{* *}$ & V6 - V10 & $2.60^{*}$ \\
\hline $\mathrm{V} 1-\mathrm{V} 5$ & $-14.05^{* *}$ & $\mathrm{~V} 2-\mathrm{V} 6$ & $-14.60^{* *}$ & $\mathrm{~V} 3-\mathrm{V} 8$ & $-56.25^{* *}$ & V5 - V6 & -1.45 & $\mathrm{~V} 7-\mathrm{V} 8$ & $-44.50 * *$ \\
\hline V1 - V6 & $-15.50^{* *}$ & $\mathrm{~V} 2-\mathrm{V} 7$ & $-12.50^{* * *}$ & V3 -V9 & $12.75^{* *}$ & V5 - V7 & 0.65 & V7 - V9 & $24.50^{* *}$ \\
\hline V1 - V7 & $-13.40^{* *}$ & $\mathrm{~V} 2-\mathrm{V} 8$ & $-57.00 * *$ & $\mathrm{~V} 3-10$ & $-11.25 * *$ & V5 - V8 & $-43.85 * *$ & $\mathrm{~V} 7-\mathrm{V} 10$ & 0.50 \\
\hline $\mathrm{V} 1-\mathrm{V} 8$ & $-57.90^{* *}$ & $\mathrm{~V} 2-\mathrm{V} 9$ & $12.00^{* *}$ & V4 - V5 & $-8.65^{* *}$ & V5 - V9 & $25.15^{* *}$ & V8 - V9 & $69.00 * *$ \\
\hline $\mathrm{V} 1$ - V9 & $11.10^{* *}$ & $\mathrm{~V} 2-\mathrm{V} 10$ & $-12.00^{* *}$ & V4 - V6 & $-10.10^{* *}$ & $\mathrm{~V} 5-\mathrm{V} 10$ & 1.15 & $\mathrm{~V} 8-\mathrm{V} 10$ & $45.00 * *$ \\
\hline $\mathrm{V} 1-\mathrm{V} 10$ & $-12.90 * *$ & $\mathrm{~V} 3-\mathrm{V} 4$ & $-3.75^{*}$ & $\mathrm{~V} 4-\mathrm{V} 7$ & $-8.00^{* *}$ & V6 - V7 & 2.10 & $\mathrm{~V} 9-\mathrm{V} 10$ & $-24.00^{* *}$ \\
\hline
\end{tabular}

The longest leaf among the investigated varieties was measured in MS-9/3 $(\bar{x}=22.65 \mathrm{~cm})$, and the shortes in Xanthi Djebel-1 $(\bar{x}=17.08 \mathrm{~cm})$. The difference in length between the two varieties is about $6 \mathrm{~cm}$. The leaves of the standard variety YV $125 / 3(\bar{x}=21.67 \mathrm{~cm})$ are about $0.98 \mathrm{~cm}$ shorter than those of the MS-9/3, and $4,60 \mathrm{~cm}$ longer than those of Xanthi Djebel-1 (Table 5).

Analysis of variance for the leaf length showed highly significant differences in 9 , significant differences in 6 and no-significant differences in 30 combinations. Compared to YV 125/3, all genotypes are not significantly different except for Xanthi Djebel-1(Table 6).

Table 5. Mean value and variability in length of the middlebelt leaves

\begin{tabular}{|l|c|c|c|c|c|c|}
\hline \multirow{2}{*}{ Varieties } & \multicolumn{7}{|c|}{ Length of the middlebelt leaves(cm) } \\
\cline { 2 - 7 } & $\bar{x} \pm \mathrm{s} \bar{x}$ & $\delta$ & $\mathrm{V}(\%)$ & $\bar{x} \pm \mathrm{s} \bar{x}$ & $\delta$ & $\mathrm{V}(\%)$ \\
\cline { 2 - 8 } & $20.73 \pm 0.41$ & 1.85 & 8.92 & $20.56 \pm 0.44$ & 1.96 & 9.52 \\
\hline V1-MK-1 & $20.40 \pm 0.39$ & 1.76 & 8.65 & $20.62 \pm 0.38$ & 1.72 & 8.32 \\
\hline V2-MK-2 & $19.95 \pm 0.39$ & 1.75 & 8.79 & $20.76 \pm 0.37$ & 1.66 & 7.99 \\
\hline V3-MB-2 & $21.22 \pm 0.40$ & 1.78 & 8.40 & $21.35 \pm 0.36$ & 1.61 & 7.56 \\
\hline V4-MB-3 & $21.95 \pm 0.37$ & 1.65 & 7.52 & $22.35 \pm 0.42$ & 1.88 & 8.40 \\
\hline V5-MS-8/1 & $22.24 \pm 0.44$ & 1.95 & 8.78 & $23.06 \pm 0.43$ & 1.93 & 8.37 \\
\hline V6-MS-9/3 & $21.88 \pm 0.38$ & 1.70 & 7.77 & $22.30 \pm 0.41$ & 1.85 & 8.31 \\
\hline V7-YZ-7 & $20.19 \pm 0.38$ & 1.69 & 8.35 & $20.97 \pm 0.27$ & 1.21 & 5.80 \\
\hline V8-PrilepBasma - 82 & $16.90 \pm 0.20$ & 0.89 & 5.26 & $17.25 \pm 0.16$ & 0.72 & 4.15 \\
\hline V9-XanthiDjebel - 1 & $21.57 \pm 0.38$ & 1.70 & 7.87 & $21.77 \pm 0.37$ & 1.64 & 7.53 \\
\hline V10 - YV 125/3 $^{\text {LSD }}$ 0.05 & 1.37 & & & 1.92 & & \\
0.01 & 2.50 & & & 3.46 & & \\
\hline
\end{tabular}

Table 6.Significance of differences in length of the middle belt leaves among varieties (from the values in Table 5) 


\begin{tabular}{|c|c|c|c|c|c|c|c|c|c|}
\hline Differ. & Signi. & Differ. & Signi. & Differ. & Signi. & Differ. & Signi. & Differ. & Signi. \\
\hline $\mathrm{V} 1-\mathrm{V} 2$ & 0.14 & $\mathrm{~V} 2-\mathrm{V} 3$ & 0.16 & $\mathrm{~V} 3-\mathrm{V} 5$ & $-1.80 *$ & $\mathrm{~V} 4-\mathrm{V} 8$ & 0.71 & V6 - V8 & $2.07^{*}$ \\
\hline V1 - V4 & -0.64 & $\mathrm{~V} 2-\mathrm{V} 5$ & -1.64 & $\mathrm{~V} 3-\mathrm{V} 7$ & $-1.74 *$ & $\mathrm{~V} 4-\mathrm{V} 10$ & -0.39 & V6 - V10 & 0.98 \\
\hline V1 - V6 & $-2.01^{*}$ & $\mathrm{~V} 2-\mathrm{V} 7$ & -1.58 & V3 -V9 & $3.28^{* * *}$ & V5 - V7 & 0.06 & $\mathrm{V7}$ - V9 & $5.02^{* * *}$ \\
\hline V1 - V7 & -1.45 & $\mathrm{~V} 2-\mathrm{V} 8$ & -0.07 & $\mathrm{~V} 3-\mathrm{V} 10$ & -1.32 & V5 - V8 & 1.57 & V7 - V10 & 0.42 \\
\hline $\mathrm{V} 1-\mathrm{V} 8$ & 0.07 & $\mathrm{~V} 2-\mathrm{V} 9$ & $3.44^{* * *}$ & $\mathrm{~V} 4-\mathrm{V} 5$ & -0.87 & V5 - V9 & $5.08^{* *}$ & $\mathrm{~V} 8-\mathrm{V} 9$ & $3.51^{* * *}$ \\
\hline
\end{tabular}

The highest dry yield among the investigated genotypes was achieved in Prilep Basma-82 $(\bar{x}$ $=19.62 \mathrm{~g} / \mathrm{stalk})$ and the lowest in Xanthi Djebel-1 $(\bar{x}=4.54 \mathrm{~g} / \mathrm{stalk})$. The highest yield among Basmak tobaccos was recorded in MS-9/3 ( $\bar{x}=16.19 \mathrm{~g} / \mathrm{stalk})$ and the lowest in MB-2 $(\bar{x}=10.01 \mathrm{~g} / \mathrm{stalk})$. The yield of the standard variety YV $125 / 3$ ( $\bar{x}=16.36 \mathrm{~g} /$ stalk) is $3.26 \mathrm{~g}$ lower than that of Prilep Basma-1, $11.82 \mathrm{~g}$ higher than Xanthi Djebel-1, $6.35 \mathrm{~g}$ higher than MB-2 and 0.17 higher than MS-9/3 (Table 7).

Analysis of variance for dry mass yield per stalkshowed highly significant differences in 35.00 significant differences in 2 and non-significant differences in 8 combinations. Compared to the YV 125/3 all genotypes are significantly different except for MS-9/3(Table 8).

Table 7. Mean value and variability in dry mass yield per stalk

\begin{tabular}{|l|c|c|c|c|c|c|}
\hline \multirow{2}{*}{ Varieties } & \multicolumn{6}{|c|}{ Dry mass yield per stalk (g) } \\
\cline { 2 - 7 } & $\bar{x} \pm \mathrm{s} \bar{x}$ & $\delta$ & $\mathrm{V}(\%)$ & $\bar{x} \pm \mathrm{s} \bar{x}$ & $\delta$ & $\mathrm{V}(\%)$ \\
\cline { 2 - 8 } & $10.31 \pm 0.04$ & 0.17 & 1.61 & $10.67 \pm 0.06$ & 0.26 & 2.42 \\
\hline V1-MK-1 & $10.24 \pm 0.06$ & 0.27 & 2.69 & $10.15 \pm 0.05$ & 0.22 & 2.15 \\
\hline V2-MK-2 & $10.03 \pm 0.07$ & 0.29 & 2.94 & $10.17 \pm 0.04$ & 0.20 & 1.99 \\
\hline V3-MB-2 & $10.34 \pm 0.06$ & 0.27 & 2.58 & $11.15 \pm 0.06$ & 0.27 & 2.43 \\
\hline V4-MB-3 & $14.74 \pm 0.08$ & 0.36 & 2.44 & $15.40 \pm 0.11$ & 0.51 & 3.32 \\
\hline V5-MS-8/1 & $15.93 \pm 0.07$ & 0.31 & 1.97 & $16.44 \pm 0.06$ & 0.29 & 1.74 \\
\hline V6-MS-9/3 & $14.21 \pm 0.08$ & 0.34 & 2.39 & $14.34 \pm 0.08$ & 0.35 & 2.46 \\
\hline V7- YZ-7 & $19.21 \pm 0.07$ & 0.32 & 1.66 & $20.02 \pm 0.06$ & 0.29 & 1.45 \\
\hline V8-PrilepBasma - 82 & $4.23 \pm 0.04$ & 0.17 & 3.92 & $4.85 \pm 0.04$ & 0.17 & 3.54 \\
\hline V9-XanthiDjebel - 1 & $16.08 \pm 0.05$ & 0.23 & 1.44 & $16.64 \pm 0.05$ & 0.23 & 1.37 \\
\hline V10- YV 125/3 & 0.90 & & & 0.98 & & \\
\hline $\begin{array}{l}\text { LSD }_{0.05} \\
0.01\end{array}$ & 1.62 & & & 1.77 & & \\
\hline
\end{tabular}

Table 8.Significance of differences in dry mass yield per stalk among varieties (from the values in Table 7)

\begin{tabular}{|c|c|c|c|c|c|c|c|c|c|}
\hline Differ. & Signi. & Differ. & Signi. & Differ. & Signi. & Differ. & Signi. & Differ. & Signi. \\
\hline $\mathrm{V} 1-\mathrm{V} 2$ & 0.30 & $\mathrm{~V} 2-\mathrm{V} 3$ & 0.10 & $\mathrm{~V} 3-\mathrm{V} 5$ & $-4.97 * *$ & $\mathrm{~V} 4-\mathrm{V} 8$ & $-8.87 * *$ & V6 - V8 & $-3.43^{* *}$ \\
\hline $\mathrm{V} 1-\mathrm{V} 3$ & 0.39 & $\mathrm{~V} 2-\mathrm{V} 4$ & -0.55 & V3 - V6 & $-6.09 * *$ & $\mathrm{~V} 4-\mathrm{V} 9$ & $6.21^{* *}$ & V6 - V9 & $11.65^{* * *}$ \\
\hline $\mathrm{V} 1-\mathrm{V} 4$ & -0.26 & $\mathrm{~V} 2-\mathrm{V} 5$ & $-4.88^{* * *}$ & V3 - V7 & $-4.18^{* * *}$ & $\mathrm{~V} 4-\mathrm{V} 10$ & $-5.62^{* * *}$ & V6 - V10 & -0.18 \\
\hline V1 - V5 & $-4.58 * *$ & V2 - V6 & $-5.99 * *$ & V3 - V8 & $-9.52^{* *}$ & V5 - V6 & $-1.12^{*}$ & V7 - V8 & $-5.34^{* *}$ \\
\hline V1 - V6 & $-5.70 * *$ & $\mathrm{~V} 2-\mathrm{V} 7$ & $-4.08 * *$ & V3 -V9 & $5.56^{* *}$ & V5 - V7 & 0.80 & V7 - V9 & $9.74 * *$ \\
\hline $\mathrm{V} 1$ - V7 & $-3.79 * *$ & $\mathrm{~V} 2-\mathrm{V} 8$ & $-9.42^{* * *}$ & $\mathrm{~V} 3-\mathrm{V} 10$ & $-6.26^{* * *}$ & $\mathrm{~V} 5-\mathrm{V} 8$ & $-4.55^{* *}$ & V7 - V10 & $-2.09 * *$ \\
\hline $\mathrm{V} 1-\mathrm{V} 8$ & $-9.13^{* * *}$ & V2 - V9 & $5.66^{* *}$ & V4 - V5 & $-4.33 * *$ & V5 - V9 & $10.53^{* *}$ & V8 - V9 & $15.08^{* * *}$ \\
\hline V1 - V9 & $5.95^{* * *}$ & $\mathrm{~V} 2-\mathrm{V} 10$ & $-6.17^{* *}$ & V4 - V6 & $-5.44 * *$ & $\mathrm{~V} 5-\mathrm{V} 10$ & $-1.29 *$ & $\mathrm{~V} 8-\mathrm{V} 10$ & $3.26^{* *}$ \\
\hline $\mathrm{V} 1-\mathrm{V} 10$ & $-5.87 * *$ & $\mathrm{~V} 3$ - V4 & -0.65 & V4 - V7 & $-3.53^{* *}$ & V6 - V7 & $1.91^{* * *}$ & $\mathrm{~V} 9-\mathrm{V} 10$ & $-11.82^{* * *}$ \\
\hline
\end{tabular}

The differences of the traits among varieties in the two years of investigation are not significant, except for the MS-8/1 in stalk height and Prilep Basma-82 in stalk height and number of leaves per stalk. This is a sign of high inheritance of the studied traits (Table 9).

The two-year biometric investigations of the quantitative traits of the varietiesshow low standard deviation and low degree of variability (Tables 1,3,5 and 7), which indicates stability and uniformity as a result of their homozygotness. 
Table 9.Significance of differences for investigated traits between years (from the values in Tables: $1,3,5$ and 7)

\begin{tabular}{|c|c|c|c|c|}
\hline \multirow{2}{*}{ Varieties } & \multicolumn{4}{|c|}{ Differencesbetween years $[\bar{x}(2013)-\bar{x}(2014)]$} \\
\hline & $\begin{array}{l}\text { height of the stalk } \\
\text { with inflorescence }\end{array}$ & $\begin{array}{c}\text { Number of leaves } \\
\text { per stalk }\end{array}$ & $\begin{array}{c}\text { Lengthof the } \\
\text { middlebelt leaves }\end{array}$ & $\begin{array}{l}\text { Dry mass yield per } \\
\text { stalk }\end{array}$ \\
\hline MK-1 & -3.50 & -0.80 & 0.17 & -0.36 \\
\hline MK-2 & -3.00 & -2.00 & -0.22 & 0.09 \\
\hline MB-2 & -3.00 & -0.50 & -0.81 & -0.14 \\
\hline MB-3 & -1.50 & -1.00 & -0.13 & -0.81 \\
\hline MS-8/1 & $-6.00 *$ & -1.30 & -0.40 & -0.66 \\
\hline MS-9/3 & -5.00 & -1.20 & -0.82 & -0.51 \\
\hline YZ-7 & -5.50 & -1.00 & -0.42 & -0.13 \\
\hline PrilepBasma - 82 & $-10.50 * *$ & $-4.00 *$ & -0.78 & -0.81 \\
\hline XantiDjebel - 1 & -2.00 & 0 & -0.35 & -0.62 \\
\hline YV $125 / 3$ & -4.00 & -2.00 & -0.20 & -0.56 \\
\hline $\mathrm{LSD}_{0.05}$ & 5.61 & 2.585 & 1.645 & 0.94 \\
\hline 0.01 & 10.095 & 4.65 & 2.98 & 1.695 \\
\hline
\end{tabular}

\section{Conclusions}

1. The highest stalk among the Basmak tobacco varieties was recorded in YZ-7, while the highest leaf number, leaf length and yield were measured in MS-9/3. The lowest stalk height and leaf number was recorded in MK-1. Variety MB-2 was characterized by the lowest length of the middle belt leaf and dry leaf yield.

2. All varieties of Basmak tobacco were significantly shorter than standard variety YV 125/3, except YZ-7 in which the difference is not significant. Compared to YV 125/3, higher leaf number was obtained in MS-8/1, MS-9/3 and YZ-7, but only in MS-9/3 it is significant. For length of the leaves from the middle belt the differences between Basmak varieties and YV 125/3 are not significant. In comparison to YV 125/3, Basmak varieties have significantly lower yield, except for MS-9/3 which lower yield is non- significant.

3. Non-significant differences in varieties between years indicate higher inheritance of the traits.

4. All investigated varieties have low standard deviation and low degree of variability, which indicates stability and uniformity as a result of their homozygotness.

\section{Acknowledgement}

The author Ana Korubin- Aleksoskaacknowledge the keen support of the Scientific Tobacco Institute and the Scientific Council of the same Institute at Prilep, St. Kicevski pat bb in the Republic of Macedonia, and also the author Mohammad Ayaz Ahmad acknowledge the collaborative support and help of the Physics Department, Faculty of Science, University of Tabuk, Saudi Arabia [8, 9].

\section{References}

[1]. Darvishzadeha R., Hatami Maleki H., 2011.Analysis of genetic variation for morphological and agronomic traits in Iranianoriental tobacco (Nicotianatabaccum L.) genotypes. Crop Breeding Journal, Vol. 2, № 1, pp. 57-61.

[2]. Dimanov D., Masheva V., 2011. New oriental tobaccos varieties of type Basma. Българскитютюн, Vol. 29, №6, pp. 23-27.

[3]. Dimanov D., Nikolova V., Popova V., 2006. Comparative technological evaluation of Zihna variety and Bulgarian tobacco varieties of the Basma ecotype. Tutun/Tobacco, Vol.56, № 5-6, pp. 109-115.

[4]. Drachev D., Nikolova V., Nikolov N., 2007.Technological qualities of Greek origin oriental tobacco.Ecology and Future, Vol. 6, № 4, pp. 38-42.

[5]. Gixhari B., Sulovari H., 2010. Nature of inheritance and heterosis estimated on some morphological quantitative characters that influence the tobacco yield. StudiişiCercetări, Vol. 33, №18, pp. 46-50.

[6]. Kichukov A., 2012. Intervju so DimitarDraganovza radio "Fokus", 20 mart.

[7]. Korubin - Aleksoska A., 2004. Tobacco varieties from Tobacco Institute - Prilep. Alfa Print - Skopje: p. 92.

[8]. Korubin - Aleksoska A; web-page of the Scientific Council members of the Scientific Tobacco Institute:http://www.tip.edu.mk/?id=sovet\&ln=en

[9]. Korubin- Aleksoska A, M. Ayaz Ahmad, (Jun.2016). Study of the Morphological and Agronomic Traits in Some Autochthonous and Commercial Tobacco Varieties in the Republic of Macedonia.IOSR Journal of Agriculture and Veterinary Science (IOSRJAVS) Volume 9, Issue 6 Ver. I, pp. 27-32.

[10]. Masheva V., Todorova R., Dimanov D., 2009. Mode of Gene Action of some traits in inter-varietal crosses of oriental tobacco ( $N$. tabacum, L.). Genetics and Breeding, Vol. 38, № 3-4, pp. 129-134.

[11]. Nikolova V., Drachev D., Nikolov N., 2005. Technological study on tobaccos of Basmi group variety grown in different regions of Bulgaria. II Technological study on tobaccos of Dzhebel sub-group variety.Biotechnology \& Biotechnological Equipment, Vol. 19, № 3, pp. 202-207.

[12]. Nikolov N., Drachev D., Nikolova V., 2009.Chemical and Technological Assessment of Tobacco Varieties of Greek Origin. Ecology and Future, Vol. 8, № 4, pp. 37-42. 